\title{
Economic Crisis Influence on FDI and Foreign Inflows in Sub-Saharan Africa Economies
}

\author{
Dr.Scholastica Achieng Odhiambo, PhD (Economics) \\ Lecturer, Department of Economics, Maseno University, Kenya
}

Doi: 10.19044/esj.2017.v13n31p557 URL:http://dx.doi.org/10.19044/esj.2017.v13n31p557

\begin{abstract}
The global economic crisis affected most of developed economies in North America and Europe which was likely to trigger a trickle-down effects on Sub-Saharan Africa. This effect was characterized by falling exports demand, foreign capital inflows in terms of foreign direct investment (FDI), foreign aid inflows and remittances from African immigrants working in the ICs. This paper investigated the effects of economic crisis on FDI and the foreign aid inflows in four countries which include Botswana, Kenya, Malawi and Mozambique. Panel data was used for analysis with OLS, Random Effects and Maximum Likelihood Estimation from 1990-2010 was conducted. The results show that contrary to the expectation that economic crisis had negative effects on FDI inflows in SSA it was the other way round. Economic crisis has a positive impact on FDI inflows. This maybe because of natural resource oriented FDIs in Mozambique and Botswana and low integration in world markets for Kenya and Malawi (Most FDI are primary resource base such as agriculture).
\end{abstract}

Keywords: Foreign direct investments, economic crisis

\subsection{Background of the Study and Problem Statement}

Increasing globalization has led to intensification of movement of goods, services, capital, knowledge, information, technology and people across countries. Interestingly there have been divergent views about the increasing globalization as opportunities and costs vary across countries. Trade and investment liberalization, technological innovations and increasingly low communication costs, entrepreneurial ventures and global social networks are the major driving forces behind globalization ( WTO, 1998; Bertucci and Alberti, 2003).

Economic globalization is largely defined by the faster expansion of international trade, foreign direct investment and capital market flows. Since late 1940s international trade has grown by leaps and bounds expanding 
rapidly than output by significant magnitude. This has been driven by low transportation costs and technological innovations particularly the internet. The internet has contributed to an increase in the volume of trade, financial flows and accelerated economic transactions by reducing the times and means of delivery and payment of goods and services ( Bertucci and Alberti, 2003) .

The globalization has eased capital movements through foreign direct investments and foreign aids to flows to less developed countries in recent years. Foreign direct investment promotes growth and employment, technology and knowhow, access to goods and services and filling the saving gap ( Arango, 2008). Foreign aid inflows stimulate economic growth through increase in aggregate savings ${ }^{17}$ and investment. Foreign aid inflows also create positive effect on growth in the case where economic growth is dependent on capital accumulation (Aurangzeb and Stengos, 2010; Ekanayake and Chatrna, 2010; Hansen and Tarp, 2001).

According to Nanto (2009) since 2007 the global economy has experienced economic upheavals across all sectors which are vital to economic growth. The advent of economic shocks in the industrialized countries financial and money markets have continuously resulted into adverse effects on key economic sectors globally. The effects of economic shocks have spread widely to both emerging and developing including those of Sub-Saharan Africa (SSA). Consequently, the prevailing economic crisis globally has had retrogressive effect on capital mobility (affecting foreign direct investment), labor market functioning, inflation, foreign exchange volatility and foreign aid inflows in SSA and globally (IMF, 2009).

Sub-Saharan Africa has been largely affected by reduced factor productivity and consumption patterns of industrialized economies (IC) such as USA and Western Europe. This effect has been characterized through falling exports demand, foreign capital inflows in terms of foreign direct investment (FDI), foreign aid inflows and remittances from African immigrants working in the ICs.

Table 1 shows statistics on GDP, FDI and foreign aid inflow in selected regions and countries before and after economic crisis during the period 2007 and 2010.

${ }^{17}$ Not one by one basis 
Table 1: GDP, FDI and Foreign Aid for Selected Regions Before and After Economic Crisis

\begin{tabular}{|c|c|c|c|c|c|c|c|c|c|}
\hline \multirow[t]{2}{*}{$\begin{array}{l}\text { Region } \\
\\
\text { Year }\end{array}$} & \multicolumn{2}{|c|}{$\begin{array}{c}\text { Foreign } \\
\text { Direct } \\
\text { Investment } \\
\text { (FDI) Net } \\
\text { Inflows (\% } \\
\text { of GDP) }\end{array}$} & \multicolumn{2}{|c|}{$\begin{array}{c}\text { Foreign } \\
\text { Direct } \\
\text { Investment } \\
\text { (FDI) Net } \\
\text { Outflows } \\
\text { flows (\% of } \\
\text { GDP) }\end{array}$} & \multicolumn{2}{|c|}{$\begin{array}{c}\text { Net official } \\
\text { Development } \\
\text { Assistance and } \\
\text { Official Aid } \\
\text { Received \$ } \\
\text { millions } \\
\text { (constant, 2009) }\end{array}$} & \multicolumn{3}{|c|}{$\begin{array}{l}\text { GDP at Market } \\
\text { Price; (annual \% } \\
\text { growth) }\end{array}$} \\
\hline & $\begin{array}{l}200 \\
7\end{array}$ & 2010 & 2007 & 2010 & 2007 & 2009 & 2007 & 2009 & $\begin{array}{l}201 \\
0\end{array}$ \\
\hline World & 4.2 & 2.1 & 4.6 & 2.3 & $\begin{array}{l}109,714 . \\
3\end{array}$ & $\begin{array}{l}127,63 \\
6\end{array}$ & 4.0 & -2.3 & 4.2 \\
\hline OECD & 4.1 & 1.6 & 5.4 & 2.6 & 1060.9 & 1627.3 & 2.6 & -4.0 & 3.1 \\
\hline USA & $2.2^{*}$ & 1.6 & 3.0 & 2.4 & - & - & 1.9 & -3.5 & 3.0 \\
\hline SSA & $\begin{array}{l}9.7 * \\
*\end{array}$ & 4.7 & 0.8 & 0.4 & $36,776.1$ & $\begin{array}{l}44,553 . \\
8\end{array}$ & 6.5 & 2.0 & 4.8 \\
\hline Botswana & 5.2 & 3.6 & 0.4 & 0.002 & 76.85 & 279.6 & 4.8 & -4.9 & 7.2 \\
\hline Malawi & $4.2 *$ & 2.7 & 0.04 & -0.4 & 738 & 772.4 & 5.8 & 7.6 & 7.1 \\
\hline $\begin{array}{l}\text { Mozambiq } \\
\text { ue }\end{array}$ & 5.3 & 8.2 & $-\overline{0} 004$ & $\overline{0}-008$ & 1800.2 & 2013.2 & 7.3 & 6.4 & 7.2 \\
\hline Kenya & 2.7 & 0.6 & 0.13 & 0.005 & 1346.6 & $\begin{array}{l}1778.3 \\
9\end{array}$ & 7.0 & 2.6 & 5.3 \\
\hline
\end{tabular}

Source of Data: World Bank, World Development Indicators (2011)

*- shows (2008); **- shows (2006)

From table 1 above foreign direct investment net inflows as percentage of GDP decreased across the world except for Mozambique between the period 2007 and 2010. The FDI decreased from $4.2 \%$ to $2.1 \%$ for the world; $9.7 \%$ to $4.7 \%$ in SSA; $5.2 \%$ to $3.6 \%$ for Botswana; $4.2 \%$ to $2.7 \%$ for Malawi; $2.7 \%$ to $0.6 \%$ in Kenya. Mozambique had an increase in foreign direct investment as \% of GDP from 5.3\% to $8.2 \%$ during the same period. Net outflows of foreign direct investment from the developed nations such as OECD and USA reduced from 5.4\% to $2.6 \%$ and $3.0 \%$ to $2.4 \%$ respectively between the period 2007 and 2010. Table 1 also reports that net official development assistance and the official aid received were not affected during the period 2007 and 2009. It increased by $16.3 \%$ for the World; $53.5 \%$ for the OECD; $21.1 \%$ for the SSA; $263.8 \%$ for Botswana; $4.7 \%$ for Malawi; $11.8 \%$ for Mozambique; and $32.1 \%$ for Kenya respectively. The annual growth in GDP dipped in 2009 and recovery for the various regions and countries emerged again in 2010 except for Malawi during the same period. According to UNCTAD (2012) FDI inflows in Africa continued to fall in 2011 though at a relatively slower rate than 2009 and 2010.

Probable causes of low FDI and foreign in Sub-Saharan Africa are varied across countries but the economic crisis has been a major concern 
since 2007. Sub-Saharan Africa economy is highly dependent on the consumption, investment and financial aid pattern of the developed economies. Therefore if these developed countries have economic problems the sub-continent is likely to suffer severe lash backs.

The aim of this paper is to determine the effects of economic crisis on foreign direct investment and foreign aid inflows in Botswana, Kenya, Malawi and Mozambique.The paper is organized as follows section 2 examines the situation for FDI and foreign aid inflows in Botswana, Kenya, Malawi and Mozambique. Section 3 consists of the literature review and section 4 consists of methodology and conclusion of the study.

\subsection{Situational Analysis for Foreign Direct Investment and Foreign Aid Inflows in Sub-Saharan Africa}

This section examines the trends in foreign direct investment inflows and foreign bilateral aid inflows in Sub-Saharan Africa with interest in Botswana, Kenya, Malawi and Mozambique.

\subsection{Foreign Direct Investment in Sub-Saharan Africa}

Foreign direct investment and foreign aid inflows to Sub-Saharan Africa (SSA) have increased in recent times with a few dips across the years. Since 1980s the foreign direct investment ${ }^{18}$ (FDI) increased from US \$ 179 million dollars and peaked to about US\$37.46 billion dollars in 2008. In 2010 it decreased to about US \$28.83 billion dollars (World Bank, 2011). Botswana, Kenya, Malawi and Mozambique have also had experienced varied growth in FDIs since 1980s. Figure 1 shows the foreign direct investment inflows (Current, US\$) for Botswana, Kenya, Malawi and Mozambique).

Figure 1: Foreign Direct Investment inflows for Selected in Sub-Saharan African

Countries.

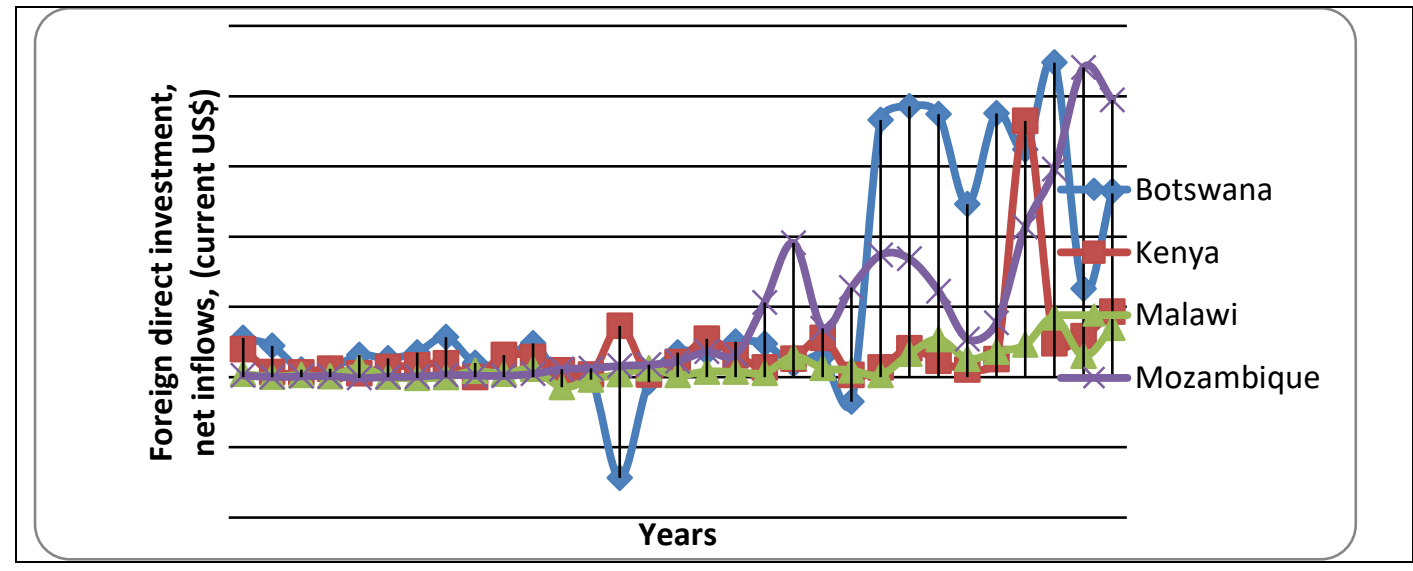

${ }^{18}$ Net inflows 


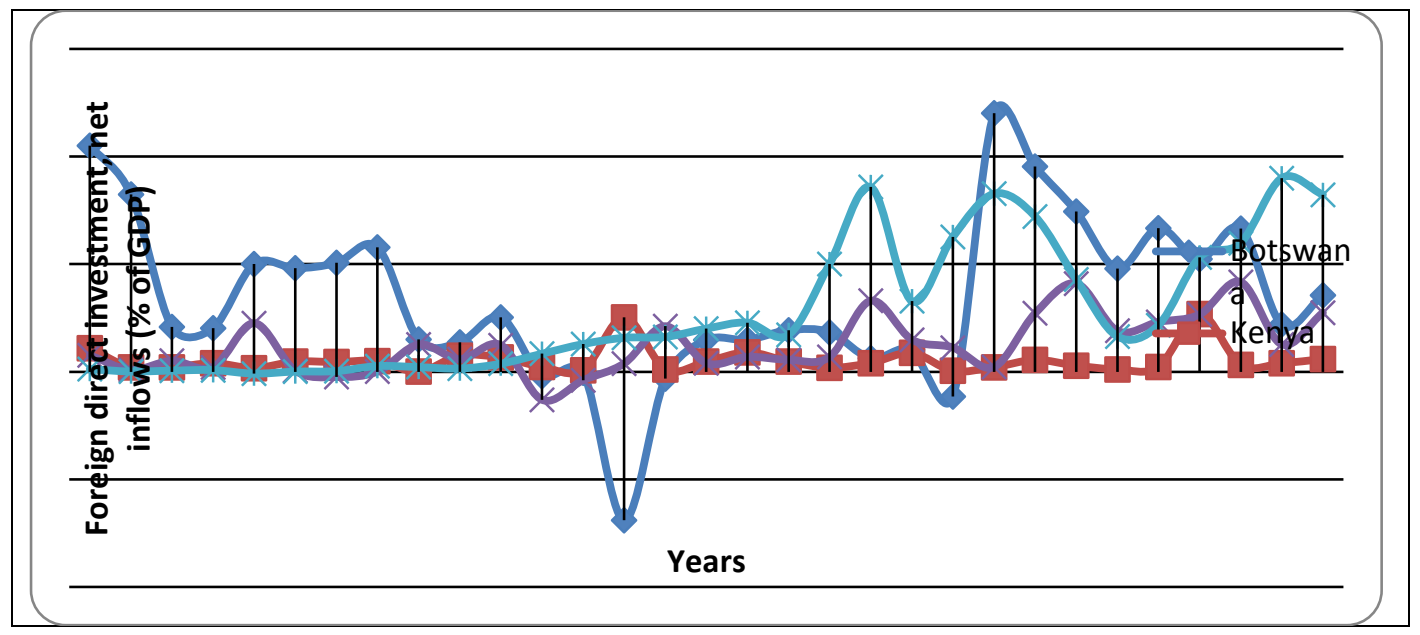

Source of data: (World Bank, 2011).

Figure 1 has two panels consisting of foreign direct investment inflows (Current, US\$) and foreign direct investment (\% of GDP). From figure 1 below Botswana has had a highly cyclical inflow of FDIs. In 1980 it had about US\$ 111 million dollars' worth of FDIs which dipped to about US\$ (-) 286 million dollars in 1993. The FDI inflows rose to a high of about US\$731.8 million dollars and peaked to US\$895 million dollars before dropping to US\$251 million dollars in 2009. Kenya has also experienced fluctuating inflows of FDIs. In comparison to the Botswana case since 1980 Kenya had about US\$ 78 million dollars' worth of FDIs. This increased to about US\$ 145.7 million dollars in 1993. Kenya experienced the highest level of FDIs inflow worth US\$ 729 million dollars in 2007 which reduced significantly to US\$ million dollars in 2008.

Figure 1 also shows that Malawi compared to Botswana and Kenya has had the lowest levels of FDIs. In 1980 Malawi had about US\$ 9.48 million dollars worth of FDIs which peaked to US\$ 107.7 million dollars in 2004 and increased further to US\$ 169.8 million dollars in 2008. FDIs inflow in Malawi dipped to about US\$ 60 million dollars in 2009. Remarkably, in comparison to Botswana and Kenya, Mozambique before 1998 had the lowest FDIs inflows only similar to that of Malawi. The turnaround from 1998 saw FDIs in Mozambique increase to US\$381.7 million dollars in 1999 which was above the other three countries FDIs. In 2009 Mozambique had one of the highest FDIs in Sub-Saharan Africa recording US\$ 881.2 million dollar worth of FDIs this decreased to about US\$ 788.9 million dollars in 2010. Sub-Saharan Africa had the highest level of FDI as percentage of GDP in 2001 of about $4.2 \%$. During the period between 2002 to 2007 it was relatively low but peaked at 3.8\% in 2008 . 
After 2008 it dipped to about 2.4\% (in 2010). The lower panel of figure 1 reflects the results in upper panel.

Figure 1 gives evidence that foreign direct investments vary and fluctuates overtime for different countries in Africa. For instance Botswana had peak of periods FDI as percentage of GDP in 1980 (10.5\%) and 2002 (12\%) respectively. On the other hand Botswana experience dips in 1993 having negative figures of FDIs as percentage of GDP. In 2008 it had about $6.7 \%$ which went down to $2.2 \%$ in 2009 with slight revival in 2010 . Figure 1 also shows that FDI as percentage of GDP was at its highest in Kenya in 1993 (2.5\%) and 2007 (2.7\%) then went down in 2008 to about $0.3 \%$. Malawi also had its peak FDI as percentage of GDP in $2004(4.1 \%)$ and 2008 (4.2\%). From 2009 it dipped to about 1.4\% in 2009 and its showing a slight recovery in 2010. Mozambique experience a rise in FDI as a percentage of GDP as from 1999 recording about 2.7\% (1999), 8.3\% (2002) and reaching its peak in 2009 (9\%). In 2010 FDI as a percentage of GDP dropped to $8.2 \%$ in 2010.Mozambique is showing a robust level of FDI as percentage of GDP compared to other four countries since 1999.

\subsection{Foreign Aid Inflows in Sub-Saharan Africa}

Foreign aid inflows in Sub-Saharan Africa have grown substantially since 1980. In 1980 Net bilateral aid from the bilateral development assistance committee (DAC) members mainly North America, Western Europe and Far East Asia (Japan) and Australia was about US\$ 5.3 billion dollars (Current). Over the years this has increased remarkably as in 1992 it peaked at about US\$14.1 billion dollars before dropping to about US\$ 9.75 billion dollars in 2000. The bilateral aid to SSA experience a recovery period having a steep growth from 2001 to 2006 where it recorded the highest level of bilateral aid over the years at US $\$ 33.1$ billion dollars. In 2007 the net bilateral aid to the sub-continent dropped to about US\$ 26.7 billion dollars and experienced a slight recovery in 2009 recording US\$ 30.8 billion dollars. 
Figure 2: Foreign Aid Inflows for Selected Countries in Sub-Saharan Africa.

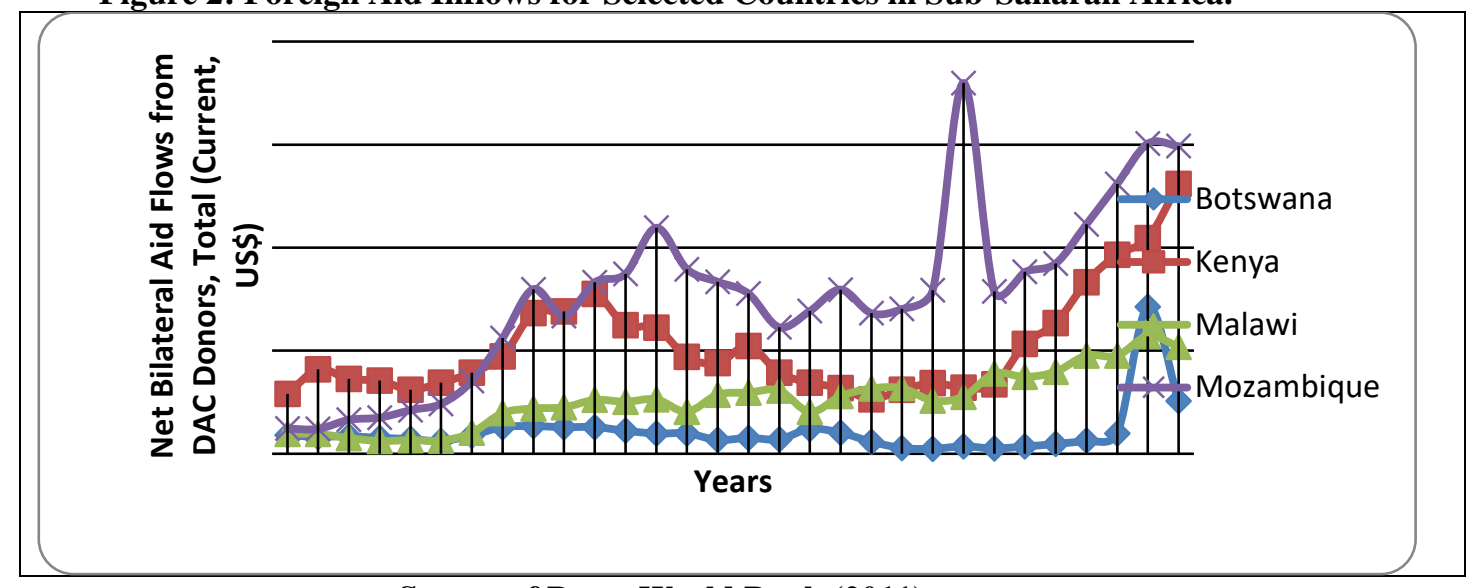

Source of Data: World Bank (2011).

Figure 2 above give trends on total net bilateral aid flows from DAC donors (Current, US\$). From figure 2 Botswana has received much lower aid inflows from bilateral donors compared to other 3 countries. Botswana reported about the peak bilateral aid inflows in 2008 of about US\$ 713.3 million dollars compared to the period between 1980 and 2007 where it averaged about US\$ 80.1 million dollars. After 2008 it dropped to about US $\$ 255.7$ million dollars.

The countries receiving the highest bilateral fund since 1980 are Kenya and Mozambique. From figure 2 Mozambique received about US\$ 1.799 billion dollars as bilateral assistance in 2002 the highest since 1980 . There was a sharp drop in bilateral aid in 2003 to about US\$ 787.3 million but it gradually US $\$ 1.5$ billion dollars in 2008 which dropped to about US\$ 1.49 billion dollars in 2009. Although Kenya has a high magnitude of bilateral aid compared to Botswana and Malawi from 1990 (US\$ 774.7 million dollars) up to 2003 (US\$ 336.3 million dollars) it experienced a decrease in the inflows. Bilateral aid improved from 2003 and it peaked to about US\$ 1.31 billion dollars in 2009. Malawi has experienced steady and gradually growth in its bilateral aid with the peak being in 2008 (US\$ 571.6 million dollars) it reduced slightly in 2009 to about US\$ 519.3 million dollars.

It is imperative to note that since 2007 FDI inflows and foreign aid inflows especially from the bilateral countries have shown a downward movement temporarily and recovery depending on the individual countries resilience.

\subsection{Literature review}

Globally countries have attracted FDI inflows through provision of multiple financial and fiscal schemes to multinational corporations (Hanson, 
2001). Artige and Nicolini (2006) note that perception on FDIs is they create jobs and provides a platform for technological transfers which leads to higher productivity to the host economy. They are also seen as productivity performance beacon of an economy.

The literature on FDI inflows as considered economic conditions of the host countries relative to the investors' home countries as the main determinants of FDI flows. According Aqeel and Nishat (2004) Dunning's eclectic paradigm (1993) suggested that it is the locational advantages of the host countries for instance market size and income levels, skills, infrastructure and political and macroeconomic stability that determines cross-country pattern of FDI.

Some empirical studies have considered the domestic market size and differences in factor cost are related to foreign direct investment ( Markusen and Maskus, 1999; Love and Lage-Hidalgo, 2000; Lipsey, 2000 and Moosa, 2002). The market size is relevant to foreign investors as it determines the economies of scale to be realized. The measures used for the market size are gross domestic product (GDP), GDP per capita and growth in GDP ( Aqeel and Nishat, 2004). Wages consists of a major part of firm costs. Higher nominal wage holding all other variables constant may deter FDI inflows especially in labor intensive industries. Various studies have found that there is either negative or no relationship between wages and FDIs inflows (Kravis and Lipsey, 1982; Wheeler and Mody, 1990; Lucas, 1993; Wang and Swain, 1995; and Barrell and Pain, 1996).There other studies which have found a positive relationship between labor costs and FDI ( Moore, 1993; Love and Lage-Hidalgo, 2000). Higher wages reflects higher productivity, hi-tech research oriented industries in which the labor quality is vital. This is because FDIs would prefer high-quality labor to cheap labor with low productivity.

Policy issues such as openness of trade, tariff, taxes and exchange rates have been used by governments to attract FDIs. Several studies have examined the relationship between these policy variables and FDIs (Gastanaga, et al., 1998; and Asiedu, 2002). They found that corporate tax rates and degree of openness to foreign direct investment to be significantly related to FDI inflows. Some studies have examined the effect of tariffs on FDIs within the context of horizontal and vertical specialization within the multinational enterprises ( Ethier, 1994, 1996; Brainard, 1997; Carr, et al., 2001).

Aqeel and Nishat (2004) explain that horizontal FDI mainly embodies market seeking behaviour and is motivated by lower trade costs. High tariff barriers are likely to induce firms to engage in horizontal FDI, and results into replacement of exports with production abroad by foreign 
affiliates. They add that "tariff jumping" theory explains that positive relationship between import duty and FDI.

\subsection{Methodology}

This section presents the methodology used in the study, econometric models, definition of variables and the data analysis and Results.

The model for determination of the effects of economic crisis on FDI inflows in Sub-Saharan Africa represented by Botswana, Kenya, Malawi and Mozambique can be presented as follows:

$F D I=f(g y$, litrate, infl, trad, gov, equity index, energy, econcrisis $)$

Where - FDI the dependent variables is measured by the net inflows as a percentage of GDP; Independent variables: $g y$ - represents the GDP growth ( annual \%); litrate- literacy rate a proxy for the education level of the labor force ( Secondary education, (\% of gross)), inflinflation; trad- trade openness measured as export plus imports divided by gross domestic product $(\mathrm{X}+\mathrm{M} / \mathrm{GDP})$; gov- International Country Risk Guide- quality of governance- to measure issues of governance (law and order, corruption and bureaucracy quality); Equity - measured by Standard and Poors Global Equity Index (for $\mathrm{OECD}^{19}$ countries) ; energy measured by energy use per capita ( $\mathrm{kg}$ of oil equivalent)-represents the level of infrastructure development; econcrisis- is the dummy variable measuring effect of economic crisis with $0=1990$ to $2006 ; 1=2007-2010$.

The study uses panel data from the year 1990 to 2010 for 4 countries which includes Botswana, Kenya, Malawi and Mozambique. The estimation methods used in the study includes Ordinary Least Squares (OLS) , Random Effects (RE) and Maximum Likelihood Estimate ( MLE). Data is sourced from World Development Indicators and UN statistical year book.

The econometric model for estimation is presented as follows;

$$
\begin{gathered}
F D I_{i t}=\varphi_{0}+\varphi_{1} g y_{i t}+\varphi_{2} \text { litrate }_{i t}+\varphi_{3} \text { inf } l_{i t}+\varphi_{4} \text { trad }_{i t}+\varphi_{5} \text { gov }_{i t} \\
+\varphi_{6} \text { energy }_{i t}+\varphi_{7} \text { econcrisis }_{i}+u_{i}+\varepsilon_{i t}
\end{gathered}
$$

The econometric results are presented in Table 2.

Table 2 presents regression results in the form of OLS (panel corrected Standard errors), random effects and maximum likelihood estimations. For the OLS estimation, the F-test is significant at $1 \% \mathrm{~F}(8,55)$ which shows the estimation has a good fit. More so R-squared showing that $32 \%$ of the FDI net inflows is explained the explanatory variables which includes

${ }^{19}$ Germany, Belgium, Canada, Spain, United Status, France, Holland, Japan, Luxembourg and Switzerland. 
Table 2: Regression Result of Effects of Economic Crisis on FDIs in Sub-Saharan Africa

\begin{tabular}{|c|c|c|c|c|c|c|c|c|c|c|c|c|}
\hline \multirow{2}{*}{\begin{tabular}{l}
\multicolumn{1}{|c}{$\begin{array}{c}\text { Estimatior } \\
\text { Method }\end{array}$} \\
Dependent \\
Variable \\
\end{tabular}} & \multicolumn{4}{|c|}{$\begin{array}{c}\text { OLS ( Panel Corrected Standard } \\
\text { Errors) }\end{array}$} & \multicolumn{4}{|c|}{ Random Effects } & \multicolumn{4}{|c|}{ Maximum Likelihood Estimation } \\
\hline & \multicolumn{12}{|c|}{ Foreign Direct Investment (FDI) } \\
\hline \multicolumn{13}{|c|}{ Independent Variables } \\
\hline & $\varphi$ & $\begin{array}{l}\text { Std. } \\
\text { Error }\end{array}$ & $\mathbf{z}$ & P-value & $\varphi$ & $\begin{array}{l}\text { Std. } \\
\text { Error }\end{array}$ & $\mathbf{z}$ & $\begin{array}{l}\text { P- } \\
\text { value }\end{array}$ & $\varphi$ & $\begin{array}{l}\text { Std. } \\
\text { Error }\end{array}$ & $\mathbf{z}$ & $\begin{array}{l}\text { P- } \\
\text { value }\end{array}$ \\
\hline $\begin{array}{l}\text { GDP } \\
\text { growth }\end{array}$ & $0.312 * * *$ & 0.077 & 4.05 & 0.000 & 0.312 & 0.121 & 2.57 & 0.010 & 0.312 & 0.113 & 2.77 & 0.006 \\
\hline $\begin{array}{l}\text { Literacy } \\
\text { Rate }\end{array}$ & $-0.044 * *$ & 0.020 & -2.15 & 0.032 & -0.044 & 0.029 & -1.50 & 0.133 & -0.044 & 0.027 & -1.62 & 0.105 \\
\hline Inflation & -.003 & 0.018 & -0.14 & 0.889 & -0.003 & 0.033 & -0.08 & 0.940 & -0.003 & 0.031 & -0.08 & 0.935 \\
\hline $\begin{array}{l}\text { Trade } \\
\text { openness }\end{array}$ & -0.016 & 0.014 & -1.13 & 0.258 & -0.016 & 0.032 & -0.50 & 0.618 & -0.016 & 0.29 & -0.54 & 0.590 \\
\hline Governance & $-7.241 * * *$ & 2.299 & -3.15 & 0.002 & -7.241 & 4.037 & -1.79 & 0.073 & -7.241 & 3.742 & -1.94 & 0.053 \\
\hline $\begin{array}{c}\text { Equity } \\
\text { Index }\end{array}$ & -0.001 & 0.002 & -0.33 & 0.743 & -0.001 & 0.017 & -0.08 & 0.940 & -0.001 & 0.016 & -0.08 & 0.935 \\
\hline Energy & $0.006 * * *$ & 0.004 & 2.92 & 0.004 & 0.006 & 0.003 & 2.33 & 0.020 & 0.006 & 0.003 & 2.52 & 0.012 \\
\hline Econcrisis & $2.115 * * *$ & 0.388 & 5.45 & 0.000 & 2.115 & 1.034 & 2.05 & 0.041 & 2.115 & 0.958 & 2.21 & 0.027 \\
\hline Constant & 3.053** & 1.271 & 2.40 & 0.016 & 3.053 & 2.175 & 1.40 & 0.160 & 3.053 & 2.016 & 1.51 & 0.130 \\
\hline
\end{tabular}


GDP growth, literacy rates, inflation, trade openness, governance, equity index, energy use per capita and the economic crisis.

In the random effect estimation, the Breusch-pagan tests show that there were no random effects and Hausmann test was insignificant. This allowed for random effect estimation. The Wald criterion test was significant chi-square (26.02; p value=0.001); The R-squared for between effects showed that $71 \%$ of the explanatory variables explained the FDI net inflows in the four countries. In the MLE estimation the likelihood ratio Chi-square (24.79; p-value=0.002) was significant showing a goodness of fit of the model.

In the three models annual GDP growth is positively and significantly related to FDI net inflows. All the estimation models shows that a $1 \%$ increase in GDP growth annually would result into $0.3 \%$ increase in FDI net inflows as a \% of GDP in the 4 countries. Education level of labor force is insignificant but with negative magnitude. The gross enrolment for secondary school in the 4 countries was quite low especially for Mozambique hence for negative relationship. Inflation and trade openness did not have significant relationship with FDI inflows in the four countries. It is import to note that most of the FDIs in Botswana and Mozambique are due to mineral endowment hence the insignificance of inflation and trade openness.

Governance showed a negative and significant relationship with FDI net inflows. The ICRG- quality of governance for the four countries are quite low indicating political conflicts (law and order), high level of corruption and low bureaucracy quality deter foreign direct investment inflows. Reduction of quality of governance by $1 \%$ will decrease FDI inflows by about $7.2 \%$. The FDI inflows have no positive relationship with S\& P global equity index across all the estimations. Energy use per capita showed a significant and positive relationship with FDI inflow. Economic crisis dummy variables show significant and positive connection with FDI inflows in the 4 sub-Saharan countries. This result is interesting as it goes against the notion that economic crisis would decrease FDI inflows in SSA. It imperative to note from the statistics the FDI inflows dropped slightly after the 2007 economic crisis but they regained their growth shortly in the four countries.

\section{Conclusion}

The study main objectives were to determine the effects of economic crisis on FDI and Foreign inflows in SSA. The results on FDI show that economic crisis has a positive and significant effect on FDI inflows. These results are of interest because the short-run effects on SSA FDI inflows dropped slightly after the economic crisis and but recovered immediately. 
Quality of governance has negative effect on FDIs inflows in SSA as they are always observed as corrupt, high level of lawlessness and high bureaucratic red tape. Energy use per capita showed a positive and significant effect on FDIs inflows.

\section{References:}

1. Aqeel, A. and Nishat, M. (2004). Determinants of Foreign Invetsment in Pakistan. The Pakistan Development Review 43(4): 651-654.

2. Arango, O.E.M. (2008). Importance of FDI in the Develoment of Emerging Countries Application to Colombia and Philippines. Center for Asia pacific Studies, EAFIT University, Colombia.

3. Artige, L. and Nicolini, R. (2006). Evidence on the Determinants of Foreign Direct Invetsment: The Case of Three Eorpean Regions. CREPP Working Paper 2006/2007.

4. Asiedu, E.(2002) .On the Determinants of Foreign Direct Investment to Developing Countries: Is Africa Different? World Development 30, 107-19.

5. Aurangzeb, Z. and Stengos, T. (2010). Foreign Aid and Economic Growth in Developing Countries: Revisiting the Evidence by Using Threshold Regression Approach. Department of Economic, University of Guelph.

6. Barrell,R. and Pain, N (1996) .An Econometric Model of U.S. Foreign Direct Investment. The Review of Economics and Statistics 78, 200-7.

7. Bertucci, G., and Adriana Alberti,A. (2003). Globalization and the Role of the State: Challenges and Perspectives. In Reinventing Government for the Twenty-First Century, State Capacity in a Globalizing Society, Rondinelli, Dennis A. and G. Shabbir Cheema (editors), Kumarian Press, Inc., CT.

8. Brainard, S. L. (1997) An Empirical Assessment of the ProximityConcentration Trade. Between Multinational Sales and Trade. American Economic Review 87:4, 520-44.

9. Carr, D. L., Markusen,J.R. and Maskus, K.E. (2001). Estimating the Knowledge-Capital Model of the Multinational Enterprise. American Economic Review 91:3, 693-708

10. Dunning, J. H. (1993) Multinational Enterprises and the Global Economy. Harrow: Addison-Wesley.

11. Ekanayake, E.M. and Chatrna,D. (2010). The Effect of Foreign Aid on Economic Growth in Developing Countries. Journal of International Business and Cultural Studies, 3:1- 13. 
12. Ethier, W. J. (1994). Multinational Firms in the Theory of International Trade. In E. Bacha (ed.) Economics in a Changing World. London: Macmillan.

13. Ethier, W. J. (1996) . Theories about Trade Liberalisation and Migration: Substitutes or Complements. In Lloyd, P. J. and L. Williams (eds.) International Trade and Migration in the APEC Region. Oxford: Oxford University Press.

14. Gastanaga, V. M., Nugent,J.B. and B. Pashamova, B. (1998) . Host Country Reforms and FDI Inflows: How Much Difference Do They Make? World Development 26:7, 1299-314.

15. Hansen, H, and Tarp, F. (2001). Aid and growth Regressions. Journal of Development Economics 64(2):547-70.

16. Hanson, G. (2001) . Should Countries Promote Foreign Direct Investment. G-24 Discussion Papers n²9, UNCTAD, Geneva.

17. IMF (2009). Impact of the Global Financial Crisis on Sub-Saharan Africa.

http://www.imf.org/external/pubs/ft/books/2009/afrglobfin/ssaglobalf in.pdf (Accessed on 7/7/2012).

18. Kravis, I. B., and Lipsey, R.E. (1982). The Location of Overseas Production and Production for Exports by US Multinational Firms. Journal of International Economics 12, 201-23.

19. Lipsey, R. E. (2000) .Interpreting Developed Countries' Foreign Direct Investment. (NBER Working Paper No. 7810.)

20. Love, J. H., and Lage-Hidalgo, F. (2000) . Analyzing the Determinants of US Direct Investment in Mexico. Applied Economics 32, 1259-67.

21. Lucas, R. E. (1993). On the Determinants of Direct Foreign Investment: Evidence from East and Southeast Asia. World Development 21:3, 391-406.

22. Markusen, J., and Maskus, K. (1999). Discriminating Among Alternative Theories of the Multinational Enterprises. (NBER Working Paper No. 7164.)

23. Moore, M. O. (1993). Determinants of German Manufacturing Direct Investment in Manufacturing Industries. Weltwirtschaftliches Archiv 129, 120-37.

24. Moosa, I. A. (2002) Foreign Direct Investment: Theory, Evidence and Practice. London: Palgrave

25. Nanto, D.K. (2009). The Global Financial Crisis Analysis and Policy Implications. Congressional Research Service. http://www.fas.org/sgp/crs/misc/RL34742.pdf ( Accessed on 7/7/2012). 
26. UNCTAD (2012). Global Flows of Foreign Direct Investment Exceeding Pre-Crisis levels in 2011, Despite Turmoil in the Global Economy. Global Investment Trends Monitor No. 8.

27. Wang, Z. Q., and Swain, N.J. (1995) The Determinants of Foreign Direct Investment in Transforming Economies: Empirical Evidence from Hungary and China. Weltwirtschaftliches Archiv 131, 359-82.

28. Wheeler, D., and Mody, A (1990) Risk and Rewards in International Location Tournaments: The Case of US Firms. Washington, D. C.: The World Bank.

29. World Bank (2011). World Development Indicators. Washington, D.C.

30. WTO (1998). Annual Report. Geneva 